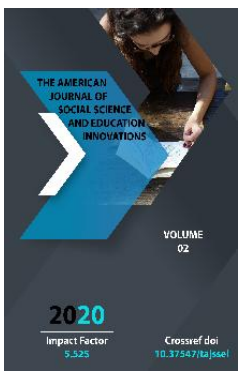

\title{
The Impact Of A Sytematic Approach In Developing An ESP Course
}

\author{
Abror Hamid Ugli Shaymardanov \\ EFL Teacher, Uzbek State World Languages University, Uzbekistan
}

Journal Website:

http://usajournalshub.c

om/index,php/tajssei

Copyright: Original

content from this work

may be used under the

terms of the creative

commons attributes

4.0 licence.

\section{ABSTRACT}

This article outlines a few modern methods and approaches in teaching ESP. ESP nowadays is a major and important part of English language teaching. The importance of needs analysis in developing curriculum for ESP course has been described. The cause of EMI growth globally has been analyzed and the usage of the modern technologies in today's classroom is discussed.

\section{KEYWORDS}

Methodology, English for Specific Purposes, Mobile Assisted Language Learning, systematic approach, Communicative Language Teaching, linguodidactics.

\section{INTRODUCTION}

Different theories about the ESP history have been analyzed so far. Hutchinson and Waters (1987) claim that there are two main events that cause to arise ESP in twentieth century: the end of Second World War and Oil Crisis. These changes played a huge role in the appearance of different ESP branches. When the English language became an international 
language around the world, the emergence of new ESP branches grew. Possessing its own characteristics and specifications teaching ESP which stands for English for Specific Purposes has grown as an inseparable and discrete part of English teaching. ESP is oriented to a particular field including terminology or knowledge of English within the scope of that sphere. It should be stated that though it is a specific part of teaching English, most scholars hold various opinions about the definitions of ESP. To illustrate, Munby (1978) defines ESP as "courses where the syllabus and materials are determined in all essentials by the prior analysis of the communication needs of the learner". This explanation is quite concise as it is considered one of the early definitions suggesting ESP courses are organized due to learner's needs. In other words, learners are exposed to an English course which they themselves put the course objectives forward. Other scholars, Hutchinson and Waters (1987) consider ESP to be an approach rather than a product. These authors claim that ESP is not restricted with the certain teaching materials or methodology; however, it focuses on a primary goal of learning English: what is learning process intended for? Robinson (1991) also defines ESP in this way that "purposeful and aimed at the successful performance of occupational or educational goals. They are based on rigorous needs analysis of students, needs should be, tailormade". Robinson makes an emphasis on two important aspects of ESP: first, it is "goaloriented" (any ESP course sets precise goals to reach at the end of the course); second, it is mostly limited in terms of time. Therefore, an ESP practitioner is required to design a course taking into consideration both students' needs and a period during which goals need to be achieved. Limited time of attaining expected objectives is highlighted in this explanation though it patently supports the above mentioned definitions by focusing on one of the critical parts of ESP, needs analysis. Agreeing with these definitions, another scholar, Streven (1988) puts it more clearly, to be more precise, he firmly believes in a wide gap between absolute and variable characteristics of ESP. Absolute characteristics of ESP can be perceived as an incident of the course with learning needs, learners' potential involvement in a certain sphere of activities and study of lexical units only pertaining to that area. Variable characteristics merely possess language abilities (they dictate that one of the language skills (e.g. writing) takes priority over others during ESP courses), and they are not taught according to any preordained methodology. Having almost identical opinions with other language experts, one of the profound scholars in ELT, Kennedy Bolitho also puts his ideas forward stating that the most essential characteristics of ESP is an investigation of the purposes of the learner and the set of communicative needs arising from those needs.

\section{MATERIALS AND METHODS}

All of these statements give a clear image of how ESP courses should be organized as well as what aspects need to be considered while dealing with them. However, a full definition is illustrated by Dudly-Evans and St John (1998) who added some detailed characteristics to Streven's definition. According to the scholars' explanation, absolute characteristics of ESP should bear the following features: a) ESP is designed to meet specific needs of the learner; b) ESP makes use of the underlying methodology and activities of the disciplines it serves; c) ESP is centered on the language (grammar, lexis, and register), skills, discourse and genres appropriate to these activities. Alongside with absolute characteristics, 
variable ones are also provided by DudlyEvans and St John just like Streven's definition: a) ESP may be related or designed for specific disciplines; b) ESP might be used in particular teaching situations, differing from general english scenarios c) ESP is probably going to be intended for the adult students, mostly in higher education or work places, and sometimes in secondary schools for high level learners; d) ESP is especially intended for upper intermediate and advanced learners; e) ESP courses include fundamental knowledge of the language.

Even though ESP possesses a number of subdivisions concerning its peculiarities, it has traditionally been divided into two main areas according to when it takes place: 1) English for Academic Purposes (EAP), and 2) English for Occupational Purposes (EOP). It should be stated as each ESP course has its own peculiarities and distinctive characteristics, scholars pool diverse opinions concerning specific characteristics of ESP courses. However, one of those language experts, Carver (1983) states that there are three characteristics common to ESP courses: a) Authentic materials (the use of authentic learning materials is possible if the claim is accepted that ESP courses should be offered at an intermediate or advanced level); b) Purpose-related orientation which refers to the simulation of communicative tasks required by the target situation. A teacher gives students various tasks to simulate the group preparation, involving the preparation time of papers, reading, taking notes, writing and etc; c) Self-direction which means that ESP is concerned with turning learners into users. For self -direction, it is necessary that teachers encourage students to have a certain degree of autonomy - freedom to decide when, what, and how they will study. For high level students it is important to learn how to obtain information in a new culture.

Characteristics of ESP illustrated by Carver are considered to be the most elaborate so far despite the fact that other suggestions have been made by many scholars. It includes most essential features of ESP courses including authentic materials in fact. Nevertheless, his opinions about usage of authentic materials are opposed in some cases because authentic materials are not always preferable for classroom usage as they make demands on learners' cognition in terms of degree of difficulty. Therefore, it is firmly believed that authentic materials should be brought into ESP classrooms after a careful selection by instructors.

\section{DIDACTIC PRINCIPLES}

This chapter represents a systematic approach towards linguodidactic fundamentals in the fields of ESP and in developing curricula for the ESP courses. When we search for the purport of the term systematic approach online, we come across with this definition "a process used to determine the viability of a project or procedure based on the experiential application of clearly defined and repeatable steps and an evaluation of the outcomes. The goal of a systematic approach is to identify the most efficient means to generate consistent, optimum results (www.investorwords.com). It can be said that a systematic approach keeps teachers up to date with the latest and evolving practice in ESP sphere.

It has been a while that stakeholders including teachers, educators, tutors and even policy makers understood the previous methods such as: Classical Method, GrammarTranslation Method, Audiolingual Method 
(ALM), and Direct Method (DM) in second language acquisition are out of date and totally obsolete. These principles are not utilized at the moment, even though they were popular in nineteenth and twentieth centuries in language teaching. Methodology has always played a huge role in second language teaching. As a result, many scholars made a lot of efforts to discover and use new methods, approaches, and principles in teaching and learning languages. In today's competitive society, Communicative Language Teaching (CLT) has been in center in second language methodology among those who belong to teaching and teacher training. Richards and Rodgers (2001) claimed that CLT is understood as an approach rather than a method. CLT theory put the central idea "Language is firstly a means of communication" forward. CLT gained its popularity when Canale \& Swain (1980) introduced a framework of the communicative competences (CC) including four subcategories: Linguistic system (grammatical competence and discourse competence) and communication (sociolinguistic competence and strategic competence). After these scholars defined communicative competences, specialists in EFL/ESL started paying more attention to CLT approach in the process of teaching foreign languages. According to Canale and Swain (1983), the definitions of these categories are the followings:

1. Grammatical Competence-"Knowledge of lexical items and rules morphology, syntax, sentence-grammar semantics, and phonology" (Canale \& Swain, 1980, p.29).

2. Discourse competence- the ability to connect the sentences in written and spoken discourses to form a meaningful series of utterances.
3. Sociolinguistic competence- the ability to adhere social and cultural rules of language.

4. Strategic Competence- the ability to utilize verbal and nonverbal open procedures to repay breakdowns in correspondence or inadequate fitness.

CLT is known for its simplicity and directness and it emphasizes on student-centered classrooms rather than teacher-centered classrooms. Therefore, more and more educators are using CLT because it perfectly suits for modern classrooms.

\section{RESULT AND DISCUSSION}

Brown D (2014) offers four interconnected qualities as a definition of CLT for the sake of simplicity and straightforwardness:

a) Classroom objectives are centered around all segments of $\mathrm{CC}$ and not confined to syntactic or grammatical competence.

b) Language procedures are intended to connect with students in the pragmatic, real and practical utilization of language for meaningful purposes.

c) Fluency and accuracy are viewed as complementary principles hidden communicative techniques. Sometimes fluency may need to take on more significance than accuracy so as to keep learners meaningfully.

d) In the communicative classrooms learners usually need to use the language, productively and receptively, in unrehearsed setting.

Studying the definitions mentioned above, it can be said that CLT might be an excellent approach in ESP classrooms as well not only to give linguistic knowledge to students but also to teach them critical thinking and creativity during the lesson. One important factor in developing curriculum for any ESP programs is 
to collect data in the form needs analysis. In finding students' needs, needs analysis is viewed as a necessary piece of decisionmaking processes before designing a course. Accordingly, needs analysis process is seen as an attempt to answer questions regarding when, where, and why language learning students need target language (Basturkmen 2010). Tending to every one of these issues, Dudley-Evans and John (1998, p.125) presents a thorough framework of needs analysis that consists of eight well-explained components. ESP needs analysis ought to go past student need and text examinations, to learn the business, require and get comfortable with the setting of the site in which it is implanted. When collecting data through needs analysis, specialists must not think in a way a one-sizefits-all English-language curriculum. So a comprehensive needs analysis should be the backbone of any ESP course.

Another significant point is to facilitate English as a medium of instruction in ESP courses in tertiary education. There are numerous instructive settings in which 'content' is educated in a language other than the home language of the understudies. These spread all the periods of training, pre-school, essential, auxiliary and tertiary just as any uncommonly structured classes for specific gatherings of understudies. Macaro et. al. (2017) outlined the growth of EMI in $\mathrm{HE}$ that "In North America the phenomenon is at times labelled 'immersion' or 'content-based learning' or 'content-based language learning' or 'contentbased language education'. In Europe, but not exclusively in Europe, it is usually labelled 'content and language integrated learning' (CLIL) or 'integrating content and language in higher education' or 'English-taught programmes'. EMI is a term used universally anywhere and, usually but not exclusively, applied to HE. The overall global view is therefore completely complex and sometimes confusing." Policy makers and especially university managers won't be affected by sociolinguistic and sociocultural problems with the execution of EMI as announced in books regarding the matter. Considering that, it is hard to see anything except further extension of EMI in HE. The utilization of the English language to show scholarly subjects (other than English itself) in nations or locales where the principal language of most of the populace isn't English. Addressing all these advantages, EMI should be implemented in ESP courses as well to engage students with target language content.

\section{CONCLUSION}

This part covers the issue of utilization of technology tools in ESP classrooms. Modern technologies bring the whole world to the classrooms if they are appropriately used in the process of teaching or developing materials for the lessons. Effective language educators should be enthusiastic and creative since language learners may lose their motivation and desire easily (Ellis, 1997:56). The types of education are evolving and the educational establishments should be open to modern trends that usually include modern technologies and online tools to keep up to date. In methodology of teaching English, new trends such as: CALL and MALL are appearing. CALL stands for computer assisted language learning, and it started to be popular in education when computers spread all around the world in the last decade of twentieth century. As mobile phones developed and became one of the part of the daily routine in human's lives, mobile assisted language learning (MALL) came out together with CALL at the beginning of this century. These kinds of modern tools give a number of 
opportunities to language teachers as well as language learners. Especially, people understood the real value of modern technologies at the present time which Covid 19 pandemic hit the world. These modern gadgets are helping both teachers and learners to facilitate the online lessons when there is not any chance for traditional face to face lessons.

\section{REFERENCES}

1. Basturkmen, H. (2010). Developing courses in English for specific purposes. Basingstoke, UK: Palgrawe/Macmillan

2. Brown. H. D: Principles of Language Learning and Teaching. NY: Pearson Education, 2014.

3. Canale, M. \& Swain, M. (1980). Theoretical bases of communicative approaches to second language teaching and testing. Applied Linguistics.

4. Carver M. Computer-Assisted Language Learning: context and Conceptualization. Oxford: Oxford University Press, 1983.

5. Egbert, Joy. Introduction: Principles of CALL, 2005, retrieved from: http://www.tesol.org/ docs/books/bk_callessentials_158

6. Ellis, Rod. The Study of Second Language Acquisition. Oxford: Oxford University Press, 1994

7. Hutchinson, T., \& Waters, A. (1987). English for specific purposes. Cambridge: Cambridge University Press.

8. Kennedy, C. \& Bolitho, R. English for specific purposes. London \& Basingstoke, Macmillan Press Ltd. 1984.

9. Munby J. Communicative syllabus design. Cambridge: Cambridge University Press, 1978.

10. Richards, J. \& Rodgers, S: Approaches and Methods in Language Teaching.
Cambridge: Cambridge University

Press, 2001.

11. Robinson, P.C. ESP today: a practitionar's guide. Hamel Hempsted: Prentice Hall, 1991.

12. Streven L. Teaching and Learning in the language classroom: Guidelines for teachers. Internet TESL Journal, Vol.3, No.10 October. 1988 - 2000, pp 5. 